\title{
THE INFLUENCE OF FLASH CARD TOWARD STUDENTS' ENGLISH VOCABULARY MASTERY DURING COVID-19
}

\author{
Hermansyah, Nurhendi \\ English Language Teaching Department, Universitas Panca Sakti Bekasi, Indonesia \\ Email: mhermansyah0486@gmail.com, hendinur20@gmail.com
}

\begin{abstract}
The purpose of this research is to see how flash cards influence the students' English vocabulary mastery. The researchers of this research used quantitative research methods with posttest only control design of true experimental design. The random sampling method was employed in this research's sampling. The data collected in this research was put to the test (multiple choice test). The researchers of this research gave different treatments for the experimental and control groups. The treatment for the experimental group was learning English with flash card media and the treatment for the control group was learning English conventionally. After the two sample groups were given different treatment, the two sample groups were each given a posttest with an instrument consisting of 20 multiple-choice questions with 4 alternative answer choices that had been tested beforehand and validated empirically. Analysis of research data is descriptive and inferential, which inferentially uses the t test, by first testing the assumptions of data normality and homogeneity of variance. The results showed that flash cards had an influence on students' English vocabulary mastery. Therefore, it can be said that this research has proved that there was a significant result of using Flash Cards towards children's English vocabulary mastery.
\end{abstract}

Keywords: flash card; vocabulary; student's English vocabulary mastery

Accepted: 23-10-2021

Revised: 12-11-2021

Publish: 20-11-2021

\section{Introduction}

Humans as social beings need a means to interact with other humans in social life. To be able to interact well, humans need a tool called language. Language is very important in life because it is used as a communication tool that makes it easier for humans to express feelings, ideas, and thoughts. There are so many languages spoken by people all over the world, one of which is English. English is one of the world's most commonly spoken languages as a second language in a lot of different countries. English is important to learn at this time because mastering English allows you to communicate with fellow citizens of the world. By mastering English you can improve

Copyright holder: Hermansyah, Nurhendi

DOI : : https://doi.org/10.54543/fusion.v1i11.101

Published by : Rifa Institute 
the quality or standard of your daily life, help you pursue educational opportunities, become a good leader in a job, and expand your social circle or friends in your life.

In this era of globalization, language has variations according to the needs of communication interactions between humans. Indonesian people need to learn and develop English in order to face global trends and difficulties in communication. Because a lot of people on the globe use English as a communication tool, it is frequently used by people as a means of talking with people in different nations. English is currently a foreign language in Indonesia. English is the first international language to play a significant role in the country's development. Each country's government seems to recognize the importance of studying English early. In Indonesia, English is the first foreign language requirement taught as one of the compulsory lessons in elementary to high school. This education policy reflects the Government of Indonesia's awareness of the importance of English as an international language.

In Indonesia, English lessons focus on students' ability to communicate. Oral and written communication are both important. Listening, speaking, reading, and writing are the four language abilities that students must understand. The first two skills are commonly referred to as receptive skills, while the other abilities are referred to as productive skills. To support their speaking and writing abilities, students must be able to have good reading and listening skills. Vocabulary is one of the basics of English learning. One of the most important language aspects for English communication is vocabulary. We will be unable to understand what everyone else is saying if we have a limited vocabulary. Listening, speaking, reading, and writing are the four language abilities that we need to learn to speak a new language. So the most important aspect of learning a new language is vocabulary. In am learning English at Elementary school. Understanding of English vocabulary is still difficult to convey to students because the teacher conveys learning only with conventional methods (Thornbury, 2006).

Using learning media is one method to make English learning more effective and efficient. It is expected that the aims of the study would be delivered as needed using the learning media. Flashcards are one of the learning media that could be used to help students increase their English vocabulary mastery. Flashcards are cards with words and pictures drawn on them. One of the media that teachers are able to use to help students increase their vocabulary mastery is flashcards. When the teachers show cards with text or pictures, students are usually able to remember English words and phrases quickly. Teachers can use flashcards to teach English in a variety of ways, including card games, puzzles, role plays, and so on. As a result, students are more interested in and enjoy the English learning process. Flashcards can also make students active in learning activities. Students can learn while playing. The researcher hopes that this flash card media can have a positive impact on English learning activities in elementary schools and can be used to make it easier for teachers to teach English vocabulary in an interesting way.

Students must have four language abilities when learning a foreign language such as English. They are listening, speaking, reading, and writing. Those four language 
abilities are intimately connected to vocabulary. Vocabulary is the basic language aspect that helps students who want to master a foreign language and have the four language skills mentioned above. There are many vocabulary definitions put forward by experts. Richards and Renandya state that vocabulary is an important part of language ability because it influences how well learners speak, listen, read, and write (Richards, Richards, \& Renandya, 2002). According to Graves and Taylor (2011), vocabulary is defined as the whole asset of words related to a type of knowledge or known by an individual. He also states that the lexicon of a language is its vocabulary, which consists of words and expressions. According to Miller and Murkolori, vocabulary is a group of words that are used as essential components for the development and comprehension of sentences and According to Linse, vocabulary is a group of words that people know (Linse \& Nunan, 2005).

Based on the definition above, vocabulary may be defined as all of the words in a language that are basic aspects of learning a language and are commonly used by people to communicate with one another. SDIT Ar Rahman Cikarang uses Flashcard media to make it much easier for teachers to give learning teaching and learning materials so the students can learn the vocabulary needed as a support for understanding the four language skills outlined before. There are a few flashcard definitions. A flashcard, according to Baleghizadeh \& Ashoori, is a piece of cardboard with simple pictures, words, or sentences on it. Teachers can use flashcards to present new words to their students in a variety of ways. Places, transportation, animals, food, and beverages Examples of vocabulary themes learnt through flashcards can be classified by kind and class (Baleghizadeh \& Ashoori, 2011). Flashcards, according to Jeremy Harmer, are small cards that the teacher can hold for students to see (Harmer, 1991). A flashcard is a basic picture on a piece of card or paper that is perhaps the most commonly used visual aid in language teaching, according to Cross. It means that flashcards are one of the media that can support a teacher in effectively teaching English. A flash card is a kind of study aid designed to present individuals with a single question related to a specific topic and is used by the teacher to make the students more active during the teaching learning process. Each flashcard is usually only an index card or a piece of paper with questions on it (Madej, n.d.).

From some of the definitions above, it can be concluded that flashcards are picture cards consisting of words and sentences used by the teacher to make it easier in explaining and introducing new vocabulary to his students. The size of flashcards varies depending on the needs of the students. They are brightly colored and are used to memorize and understand new languages. Additionally, flashcards are one of the visual aids used to make the teaching and learning process more interesting and fun for students, as well as to improve students' understanding of the lesson presented by the teacher.

Before Covid-19, researchers usually performed face-to-face research in class with students using flash cards. The problem regarding the application of flash cards at this time is by conducting distance learning during covid-19 where researchers cannot 
directly meet face-to-face in class with students. As for students, they are not used to learning using distance learning forms. If this is studied in depth and detail, it will cause problems with the limitations of time, distance, and existing capabilities. Researcher are currently trying to do the latest research on distance learning in contrast to previous research. Usually teachers use flash cards for learning English before the Covid-19 period in class, but when Covid-19 occurs researchers cannot do it in class. adjusted for the time of covid-19. With this research, it is hoped that teachers will get references on how to improve students' English vocabulary using flashcards to help and support students in speaking English skills first during distance learning (Mukoroli, 2011).

It is hoped that this research will contribute new ideas and thoughts to the learning process, especially for the use of flashcards as a medium in learning English to improve vocabulary skills in English, in order to help students learn and develop English speaking skills and the other three skills that have been mentioned before. As a result, teachers must be more creative and innovative in their use of learning techniques, methods, and media so that students do not become bored.

\section{Method}

Research methods are procedures or steps in obtaining scientific knowledge or knowledge. So the research method is a systematic way to compile science. This kind of research is experimental quantitative research in processing and obtaining data results. This research methodology is classified as experimental research with a comparative approach. Flash cards were the independent variable in this research, while the students' English vocabulary mastery was the dependent variable. The researcher conducted experiments or treatments on two different sample groups, namely the experimental group and the control group, with the purpose of going to compare the post-test results between the two groups. Experimental research is a type of study that is done to see how various treatments influence others in a controlled environment (M. P. P. Sugiyono $\&$ Kuantitatif, 2009). The comparative research method is a study that compares the existence of a variable or more in two or more different samples, or at different times (Dr Sugiyono, 2013).

The experimental design employed in this research is a true experimental design with a posttest only control design. True Experimental is a real experiment, according to Sugiyono (2012:112), because the researcher can manage all external variables that influence the experiment's results. The following is a description of the experimental design used in this research:

$$
\begin{array}{lll}
\mathrm{R}_{\mathrm{E}}: & \mathrm{X} & \mathrm{O}_{1} \\
\mathrm{R}_{\mathrm{K}}: & \mathrm{Y}^{\mathrm{O}_{2}}
\end{array}
$$

\section{Figure 1. Research Design}




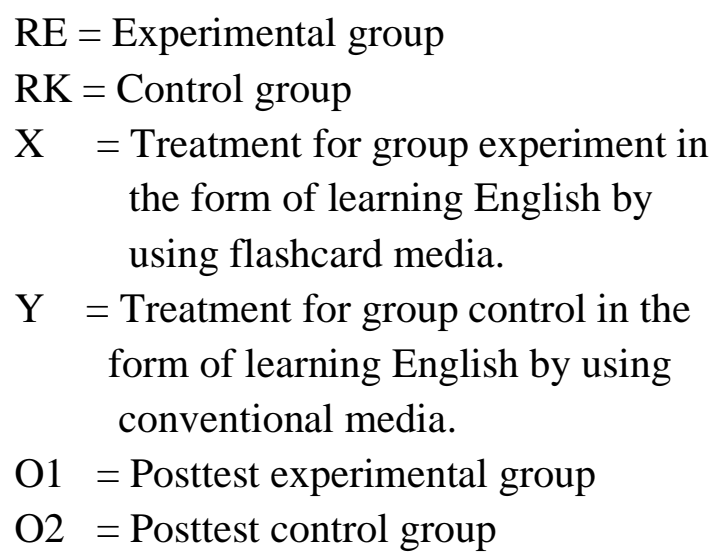

In this research, the population consisted of all students in class VI at SDIT Ar Rahman Cikarang Selatan in the academic year 2020/2021, with a total of 100 students divided into four parallel classrooms. Population is defined by Sugiyono as a generalization region made up of items or subjects with specific characteristics and specifications that the researcher investigates and then draws conclusions from (Dr Sugiyono, 2013). The researcher used two classes as samples in this study. The experimental group will be one class, while the control group will be the other. According to Sugiyono, the sample is a part of the population's number and characteristics (M. P. P. Sugiyono \& Kuantitatif, 2009). The researcher used simple random sampling as a sample technique in this study. It was used to determine the experimental and control groups via random or shuffling. Class VI Nusaibah was chosen as the experimental group, with 25 students, and class VI Sa'ad was chosen as the control group, with 25 students.

Data is a very important element in research. Collecting data in addition to using theory. The results of the research must be carried out in the presence of empirical data that is actually obtained in obtaining data. The learning outcome exam was used to collect data for this research. According to Suharsimi Arikunto (2010: 193), a test is a set of questions or exercises, as well as other instruments, that are used to examine an individual's or group's skills, knowledge, intelligence, ability, or talent (Barst \& McGoon, 2003).

To facilitate data collection in research, research instruments are needed so that research results are more accurate, complete and systematic. Data collection in this study was carried out by collecting instrument data in the written form objective tests multiple choice form tests as many as 20 questions with answer choice instruments $\mathrm{a}, \mathrm{b}, \mathrm{c}$ and $\mathrm{d}$ which were adapted to subject matter related to English vocabulary. To get test scores, the researcher gave points for each number of questions. For the correct answer, you will be given 1 point, and for the wrong answer, you will be given zero. Before the test is used in data collection, the test must be tested first to obtain valid and reliable research data.

Validity is a concept related to how well a test has measured what it is supposed to measure (Surapranata, 2004). A validity test can be performed to verify the accuracy of an instrument or test that researchers use to measure and collect data from 
respondents. When a test or measuring instrument fulfills its measuring function or produces measurement results that are consistent with the measurement objectives, it is said to have high validity. While reliability comes from the words "reliable" and "ability," Measurements that have high reliability are called reliable measurements. According to Suharsimi Arikunto, reliability demonstrates an understanding that an instrument can be trusted to be used as a data collection tool since the instrument is good (Hughes \& Hitchcock, 2008). The validity and reliability of the contents of the instrument in this study were tested by the researchers on students who were not included in the research sample, namely 30 parallel class students from the research place with instruments in the form of multiple choice questions as many as 20 items with 4 alternative answer choices a, b, c or d using the SPSS application. With the results of the validity coefficient that appears in the range of 0.365 to 0.718 . So based on the results, the item is declared valid because $r$ count is greater than $r$ table of 0.361 with a significance level of $5 \%$. While the results of the instrument reliability are in the very high category with a score of 0.902 .

The researchers began conducting research with treatments using flashcards for the experimental group and conventional treatment for the control class after the validity and reliability tests were certified valid and reliable. After doing the treatment of the two groups, the researcher did a test to see if there was a difference in learning results between the groups using flash cards and conventional treatments. Based on the instructions of the central government (Kemendikbud) by paying attention to the process of spreading and the threat of Covid-19 that has hit the world, including Indonesia. Due to the impact of Covid-19, all educational institutions (schools and campuses) must adapt teaching and learning activities in class (face to face) with distance learning (online). As a result, the researchers used the zoom application to deliver flash card treatment to the experimental group and conventional treatment to the control group, as well as collect the required learning outcomes data. The steps for collecting data through the zoom application that researchers use are as follows:

1. The researcher invites students both in the experimental and control groups to join the zoom meeting to get treatment using flash cards and conventional treatment and get learning data results by distributing zoom links to groups of students who are in the experimental group and control group within a time span different.

2. After all students who were in the experimental and control groups joined the zoom meeting. The researcher ensures that students activate the video and audio modes on the zoom application so that researchers can ensure that learning and taking tests are in proper conditions.

3. Researchers provide treatment using flash card media for the experimental group and conventional treatment for the control group by activating share screen on the zoom application so that students can see an overview of the treatment using flash cards and conventional treatment. The series of steps in teaching using flash card media and conventional teaching using the Zoom Meeting application 
are as follows:

a. Treatment using flash cards:

- The researcher shows the front of the card (which contains pictures and words in English) to students through the share screen in the zoom application.

- The researcher reads word by word in English according to the pronunciation (how to read it) then reads the meaning so that the child understands.

- The researcher reads word by word on the card aloud with the correct way to read it and invites the students to follow what the researcher says.

- The researcher repeated the reading several times until the English pronunciation spoken by the students was good and correct.

- Researchers carry out the activities mentioned in the previous steps repeatedly and consistently, so that students can learn systematically so that their absorption in remembering will be more optimal.

b. Treatment using conventional methods:

- The researcher writes down word by word in English along with its meaning to the students through the share screen in the zoom application.

- The researcher reads the English word by word that has been written according to the pronunciation (how to read it) and its meaning into Indonesian.

- The researcher reads word by word on the card aloud along with how to read it and invites the children to follow it.

- The researcher repeated the reading several times until the English pronunciation spoken by the child was good and correct.

- Researchers carry out the activities mentioned in the previous steps repeatedly and consistently, so that students can learn systematically so that their absorption in remembering will be more optimal.

4. After the experimental group and the control group were both treated with the same teaching materials, The researcher gave an objective test consisting of 20 multiple choice questions with the answer choice instruments $\mathrm{a}, \mathrm{b}, \mathrm{c}$ or $\mathrm{d}$ as a post-test to the students at the next meeting. Giving the test is still using the zoom application. When using the zoom application, the researcher activates the share screen mode so that students can see the form of multiple choice questions with choice instruments a, b, c and $d$ that have been prepared by the researcher. The duration of each question given is 30 seconds per question. After 30 seconds, the question will move to the next question. The process keeps repeating until the 20th question. Researchers provide opportunities for students to look back at the form of the question with the aim that students who have not finished answering all the questions can complete it. The number of questions is adjusted to the scope of the material provided and the learning time that has been set at SDIT Ar Rahman Cikarang Selatan. This test is intended to compare learning outcomes using flash card media and conventional media. Before the post-test was conducted, the researcher asked the students to direct and set their cellphone or laptop camera to the students and the answer sheet. This is 
done by the researcher so that the researcher can ensure that the test is carried out under proper conditions without the intervention of other parties in helping the test work. After completing the test, the researcher asked the students to show the answer sheet that had been filled in with the answers to the camera so that the researcher could record or take a picture of the answer sheet that had been filled in with the answers so that the researcher could process it by giving an assessment of the tests that had been done by the students (Fitriyani \& Nulanda, 2017).

The researcher believes that flash cards had an influence on students' English vocabulary mastery in this research. after describing the results of posttest calculations between the experimental group using flash cards and the control group using the conventional method. The analysis of the test was performed by testing the normality and homogeneity of the data. After obtaining normal and homogeneous data, followed by hypothesis testing using the $\mathrm{t}$ - test.

\section{Results And Discussion}

The experimental and control groups in this study were given different treatments by the researcher. The experimental group received flash card media as part of their treatment, while the control group received conventional English teaching as part of their treatment. In this research, the study materials and the number of meetings for each sample group were equated to both the number of meetings and the duration of learning. This study's data comes in the form of students' English learning results, which are examined via a posttest. The value of English learning outcomes is based on 20 multiple choice questions that may be obtained of value at least 0 and a maximum of 100. The data of this research are presented in table 1 in descriptively.

Table 1: Descriptive Statistics Calculation Results Summary

\begin{tabular}{lcc}
\hline & $\begin{array}{c}\text { Experimental Group } \\
\text { Posttest Learning } \\
\text { Outcomes }\end{array}$ & $\begin{array}{c}\text { Control Group } \\
\text { Posttest Learning } \\
\text { Outcomes }\end{array}$ \\
\hline $\mathrm{N} \quad$ Valid & 25 & 25 \\
Mean & 0 & 0 \\
Std. Error of Mean & 79.40 & 74.80 \\
Median & 1.509 & 1.306 \\
Mode & 80.00 & 75.00 \\
Std. Deviation & 75 & 75 \\
Variance & 7.544 & 6.532 \\
Range & 56.917 & 42.667 \\
Minimum & 30 & 25 \\
Maximum & 65 & 60 \\
Sum & 95 & 85 \\
& 1985 & 1870 \\
\hline
\end{tabular}


The summary of the results of descriptive statistical calculations from the table above is as follows:

\section{Experimental Group Posttest Results}

The results of the posttest conducted in the Experimental group after using flash cards with a total sample or respondent of 25 students with the lowest score of 65 and the highest score of 95, with an average score (mean) of 79.40, a score range of 30, standard deviation of 7.544, the highest score frequent (mode) of 75, and the median of 80.00 .

\section{Control Group Posttest Results}

The results of the posttest conducted in the control group using the conventional method with a sample size of 25 students with the lowest score of 60 and the highest score of 85 , with an average score (mean) of 74.80, a score range of 25, the standard deviation of 6,532, the highest frequency score (mode) of 75, and the median of 75.00.

The average posttest score for the experimental group is 79.40, while the average posttest score for the control group is 74.80, as can be seen from the explanation above. This suggests that the experimental group and the control group had different outcomes in terms of English learning. However, this still requires further testing through the precondition test of data analysis, which is the assessment of the data's normality and homogeneity. The normality test was performed on two sets of data: the experimental group's posttest data and the control group's posttest data. In this study, the normality test was obtained using the Kolmogorov-Smirnov test or the Shapiro-Wilk test using the SPSS application.

For more details, the results of the normality test for the experimental group and control group can be seen in the following table:

Table 2. Results of the Normality Test Calculation

\begin{tabular}{llcccccc}
\hline & & \multicolumn{4}{c}{ Test of Normality } & \multicolumn{3}{c}{ Shapiro-Wilk } \\
& \multicolumn{1}{c}{ Class } & Solmogorov-Smirnov & \multicolumn{3}{c}{} \\
& \multicolumn{1}{c}{ Static } & df & Sig & Statistic & df & Sig \\
\hline \multirow{2}{*}{ Result } & Experimental Posttest & .160 & 25 & .098 & 0.947 & 25 & .211 \\
& Control Posttest & .152 & 25 & .138 & .940 & 25 & .149 \\
\hline
\end{tabular}

According to the table above, the sig value for the experimental group's normality test using the Kolmogorov-Smimov test was $0.98>0.050$, while the control group's sig value was $0.138>0.050$, while the normality test for the Experimental group using the Shapiro-Wilk test resulted a sig value of $0.138>0.050$. The experimental group data has a sig value of $0.211>0.050$, while the control group data has a sig value of $0.149>0.050$, so that the conclusion from this distribution showing that the experimental and control group data are from a normally distributed population. Because the research data is normally distributed, the research can be extended by 
putting other data analysis criteria to the test, such as the homogeneity of variance test. The purpose of homogeneity testing is to see if the data from each sample group has the same variance. The following table summarizes the detail of the Homogeneity of Variance Test for the experimental and control groups in more detail:

Table 3. Summary of Homogeneity of Variance Test Calculation Results

\begin{tabular}{|c|c|c|c|c|c|}
\hline \multicolumn{6}{|c|}{ Test of Homogeneity of Variance } \\
\hline & & Statistic & df1 & df 2 & Sig. \\
\hline Learning & Based on Mean & .449 & 1 & 48 & .506 \\
\hline \multicolumn{6}{|l|}{ Outcomes } \\
\hline & Based on Median & .411 & 1 & 48 & .524 \\
\hline & $\begin{array}{c}\text { Based on Median and with } \\
\text { adjusted df }\end{array}$ & .411 & 1 & 47.032 & .525 \\
\hline & Based on trimmed mean & .524 & 1 & 48 & .473 \\
\hline
\end{tabular}

Based on the table above, the sig value based on the average value is $0.506>$ 0.05 , indicating that the data variance of the post-test experimental group and the control group is homogeneous, and so one of the independent sample $t$ test requirements (not absolute) has been met.

After all of the data analysis requirements have been completed in inferential statistical analysis, the calculations are carried out using the Test Independent Sample T test. The test was used to see if there was a difference between the means of two unpaired samples. This exam is used to answer the question "Do flash cards have an influence on students' English vocabulary mastery?" The experimental group's posttest data was tested using a flash card, while the control group's posttest data was tested using the conventional methods. The average difference in the posttest scores of the experimental group and the control group is presented in the following test results.

The sig value was calculated using the results of the mean difference test for the two sample groups. It may be determined that there is a difference in average student learning outcomes between learning models using flash cards and conventional models. The results of the calculation of the mean difference test for the two sample groups obtained the sig value (two-tailed) of $0.026<0.05$. For more details, to find out the average The post-test of the experimental and control groups can be found in the following statistical table:

Table 4. Summary of Group Statistics Calculation Results

\begin{tabular}{cccccc}
\hline & Group & $\mathrm{N}$ & Mean & $\begin{array}{c}\text { Std. } \\
\text { Deviation }\end{array}$ & $\begin{array}{c}\text { Std. } \\
\text { Error Mean }\end{array}$ \\
\hline $\begin{array}{c}\text { Learning } \\
\text { Outcomes }\end{array}$ & $\begin{array}{c}\text { Experimental } \\
\text { Posttest } \\
\text { Control }\end{array}$ & 25 & 79.40 & 7.544 & 1.509 \\
& 25 & 74.80 & 6.532 & 1.306 \\
& Posttest & & & & \\
\hline
\end{tabular}


The average score of students' English using flash cards is 79.40, while the average score of students' English using conventional methods is 74.80, as shown in the table above. As can be seen from these results, students who use flash cards have much better English learning results than students who study conventionally. It can be concluded from the outcomes of testing this hypothesis that there is an influence of flash cards towards students' English vocabulary mastery.

\section{Discussion}

Students' mastery of English vocabulary improves when they use flash cards. Teachers' use of flash cards can help students in developing their English vocabulary mastery. According to the research findings, there are differences in learning outcomes between groups of students who use flash cards and groups of students who use conventional methods. Table 4 shows that students who use flash cards have an average English score of 79.40, while students who use conventional methods have an average English score of 74.80. As can be seen from the results mentioned above, the average value of the group of students who use flash cards is much greater than the average value of students who study conventionally.

Based on the results and data obtained, it can be said that learning English to improve students' English vocabulary mastery using flash cards is one of the effective learning alternatives that can be used in the learning process. Thus the working hypothesis in this study is supported by empirical data. The results of this study support the opinion of Eka Fitriyani, Putri Zulmi Nulanda (2017), They stated "Flash cards can help students learn to focus more and be able to recognize words easily. Based on the results of observations in the field, students become very excited and enthusiastic about learning vocabulary. Therefore, flash card media is very suitable to be used for learning English, especially to improve students' vocabulary mastery.

In this research, researchers conducted research during the time of COVID 19, which required students to do distance learning. With this research, it is hoped that teachers will get references on how to improve students' English vocabulary to help and support students in mastering speaking skills using English moreover when studying distance.

\section{Conclusion}

The mastery of grade VI students of SDIT Ar Rahman Cikarang Selatan in the 2020/2021 school year for the group of students who used flash media, students' mastery of English vocabulary was higher than the vocabulary mastery of the group that did not use flash cards. The data can be seen from the average value of the post-test of the two groups. The "very good" category was obtained by the group of students who used flash cards with an average score (79.40) while the post test scores of students who did not use flash cards (74.80). Based on these results, it can be said that flash cards 
Hermansyah, Nurhendi

have a significant effect on increasing students' English vocabulary skills. Flash cards can help students learn to focus more and can recognize words easily. Based on observations in the field, students became very enthusiastic and enthusiastic in learning English, especially for the vocabulary theme. Flash cards can be used by teachers as learning media, both individually and in pairs while coming to the front of the class, so that students can learn while playing and increase their interest in learning vocabulary. The use of flash cards as learning media also makes students brave and not ashamed to appear in front of the class. 
The Influence Of Flash Card Toward Students' English Vocabulary Mastery During Covid-19

\section{BIBLIOGRAFI}

Baleghizadeh, Sasan, \& Ashoori, Arezoo. (2011). The impact of two instructional techniques on EFL learners' vocabulary knowledge: Flash cards versus word lists. Mextesol Journal, 35(2), 1-9. Google Scholar

Barst, R., \& McGoon, M. (2003). Arikunto, Suharsimi. 2010. Prosedur Penelitian: Suatu Pendekatan Praktik. Jakarta: Rineka Cipta Badesch, D., Barst, R., Delcroix, M., McLaughlin., Olschewski, H., Sitbon, O V. and Vizza, C. 2004. Prostanoid therapy for pulmonary arterial hypertension. Journal of the American College of Cardiology; 43 (12): 56. Cardiology, 41(12), 2119-2125. Google Scholar

Fitriyani, Eka, \& Nulanda, Putri Zulmi. (2017). Efektivitas Media Flash Cards dalam Meningkatkan Kosakata Bahasa Inggris. Psympathic: Jurnal Ilmiah Psikologi, 4(2), 167-182. Google Scholar

Harmer, Jeremy. (1991). The practice of English teaching. London \& New York: Longman, 175. Google Scholar

Hughes, David, \& Hitchcock, Graham. (2008). Arikunto, Suharsimi, Prosedur Penelitian Suatu Pendekatan Praktik, Jakarta: PT. Rineka Cipta, 2006, Cet. 6. Unpublished Thesis. Google Scholar

Linse, Caroline, \& Nunan, David. (2005). Practical English language teaching: young learners/by Caroline T. Linse; David Nunan, series editor. Google Scholar

Madej, Joanna. (n.d.). Teaching vocabulary related to British customs and traditions through audio-visual aids. Google Scholar

Mukoroli, Joseph. (2011). Effective vocabulary teaching strategies for the English for academic purposes ESL classroom. Google Scholar

Richards, Jack Croft, Richards, Jack C., \& Renandya, Willy A. (2002). Methodology in language teaching: An anthology of current practice. Cambridge university press. Google Scholar

Sugiyono, Dr. (2013). Metode penelitian pendidikan pendekatan kuantitatif, kualitatif dan $R \& D$. Google Scholar

Sugiyono, M. P. P., \& Kuantitatif, P. (2009). Kualitatif, dan R\&D, Bandung: Alfabeta. Cet. Vii. Google Scholar

Surapranata, Sumarna. (2004). Analisis, Validitas, Reabilitas dan Implementasi Hasil Tes Implemntasi Kurikulum 2004. Bandung: PT Rosdakarya. Google Scholar

Thornbury, Scott. (2006). How to teach vocabulary. Pearson Education India. Google Scholar 
Hermansyah, Nurhendi

First publication right:

Jurnal Syntax Fusion: Jurnal Nasional Indonesia

This article is licensed under:

(c) (i) (2) 